\title{
[審査付論文（研究論文）]
}

\section{不動産取得税に係る用途非課税の適用要件 \\ 一学校法人が学校用地とする目的で土地を取得した場合を素材として一 \\ The Theory of Tax Exemption Requirements of Real Estate Acquisition Tax}

Nobuyuki KOBAYASHI : Kobe University

小林 伸幸*

When an incorporated educational institution acquires real estate to establish a school, real estate acquisition tax is tax exemption. There are two interpretations of this tax exemption requirements. One is interpretation that acquisition of real estate to establish a school is a tax exemption requirement. The other is interpretation that the establishment of a school is a tax exemption requirement. This paper discusses this tax exemption requirements, accreditation standards of this tax exemption requirements, and limited interpretation of this tax exemption requirements.

\section{1 はじめに}

国有地の売却価格の妥当性や小学校の設置認可 の適否等に関して社会的な関心を集めた ${ }^{(1)}$ 学校法 人森友学園（以下「学園」という）が不動産取得 税を滞納したとして，大阪府（以下「府」とい う）は，学園が所有する土地を差し押さえた ${ }^{(2)}$ その後, 同税は納付された ${ }^{(3)}$ 。同税は, 学園が設 置を目指していた小学校の用地とするために土地 を取得したことに対するものであり，学園が同小 学校の設置認可申請を取り下げたことから課され たものである(4)。
ところで, 不動産取得税とは, 「不動産の取得」 (地方税法（以下「法」という） 73条の 2 第 1 項) を課税客体とする道府県税（同 1 条 1 項 4 号, 4 条 2 項 4 号参照）であるが, 一定の要件を満たす 場合は非課税とされる（同73条の 3 から 73 条の 7 参照)。その中には, 学校法人, 宗教法人, 社会 福祉法人等の公共的性格を有する者が, 法73条の 4 第 1 項各号に規定する用途一一例えば，学校用 地, 境内地, 社会福祉事業の用途一 (同項各号 に規定する用途を，以下「非課税用途」という） に供するために不動産を取得した場合を非課税と するものがある（同項に基づく非課税を，以下

小林 伸幸* (こばやし のぶゆき) 正会員・神戸大学大学院法学研究科博士課程後期課程 2 年

（1）この問題に関しては, 衆参両議院予算委員会において, 学園理事長に対する証人喚問が行われた（第193回国会衆議院予算委員会 議録第18号〔平成29年 3 月23日〕 1 1 頁, 第193回国会参議院予算委員会会議録第15号〔平成29年 3 月 23 日〕 $1 １ 6$ 頁参照)。また, 会計検查院「会計検查院法第30条の 3 の規定に基づく報告書『学校法人森友学園に対する国有地の売却等に関する会計検查の結果 について』[平成29年11月]」116頁（同院HP(http://www.jbaudit.go.jp/pr/kensa/result/29/pdf/291122_zenbun_1.pdf[最終確認日： 平成29年12月 1 日])）は, 当該国有地の売却等に関して,「合規性, 経済性等の面から, 必ずしも適切とは認められない事態や, より慎重な調查検討が必要であったと認められる事態等が見受けられた。と指摘する。

(2) 朝日新聞平成 29 年 5 月 27 日朝刊 35 面, 産経新聞平成 29 年 5 月 27 日朝刊 28 面, 日本経済新聞平成 29 年 5 月 26 日夕刊 15 面, 毎日新聞平 成 29 年 5 月 26 日夕刊 9 面, 読売新聞平成 29 年 5 月 27 日朝刊 34 面参照。

(3) 朝日新聞平成 29 年 5 月 31 日朝刊 30 面, 産経新聞平成 29 年 5 月 31 日朝刊 26 面, 日本経済新聞平成 29 年 5 月 31 日朝刊 39 面, 毎日新聞平 成 29 年 5 月 31 日朝刊 28 面，読売新聞平成 29 年 5 月 30 日夕刊 10 面参照。

(4) 前掲注 $(2)$ 及び $(3)$ 参照。 
「用途非課税」という)。このうち，学校法人に対 する非課税として, 同項は, 「学校法人……がそ の設置する学校において直接保育又は教育の用に 供する不動産」(同項 3 号)「として使用するために 取得した場合には, ……不動産取得税を課するこ とができない。」(同項柱書) と規定する。同項は, 「使用するために取得した場合」を非課税とする から、これを素直に読めば，「使用するために取 得し」, その後, 実際に「直接保育又は教育の用 に供」しなかったとしても, 非課税となりそうで ある。

しかしながら, 府は, 学園が小学校の設置認可 申請を取り下げたことから不動産取得税を課して いる(5)。その経過は, 次のとおりである。すなわ ち, 平成26年10月31日に学園が同申請を行ったと ころ ${ }^{(6)}$, 平成 27 年 1 月 27 日に大阪府私立学校審議 会において「条件を附して認可適当と認める。」 という結論が出された(7)。平成28年 6 月20日に学 園は同小学校の用地とするために土地を取得した が(8), 平成29年 3 月 10 日に学園は同申請を取り下 げた ${ }^{(9)}$ 。当該取下げに関し, 学園理事長（当時） は, 衆議院予算委員会において,「今の状況で考 えると, どうもこれは私学審議会で答申はおりな い」という代理人弁護士の意見を聴いて取り下げ たと証言している ${ }^{(10)}$ 。これに対し, 同申請の適否 を判断する府知事は, 「私学審に出される書類に, 今回虚偽がすごく疑われているけど，そのような いいかげんなものが出てきているなんて, 私学審 のメンバーも私学課も誰もわからない。」「書類が 全て正しい，虚偽がなければ，〔平成29年〕4月 1
日に〔同小学校は〕開設できていますよ。」とい う認識を示している(11)。こうした経過の中で府は 不動産取得税を課しているが, 学園が当該土地を 取得した時点においては,「その設置する学校に おいて直接……教育の用に供する不動産」「として 使用するために取得した場合」に該当するように 思われる。

そこで, 本稿では, 学園に課された不動産取得 税を素材として, 用途非課税の適用要件を検討す る。具体的には, まず, 用途非課税の趣旨を確認 する (後記 2 )。次に, 用途非課税の適用要件と して，実際に非課税用途に供することが含まれる か否かを検討する（後記 3 )。次に, 用途非課税 の適用要件に関する事実認定の基準を検討する (後記 4 )。最後に, 用途非課税の適用要件を厳格 に解釈した上で（後記 5.1 ），学園に対する用 途非課税の適否を検討する（後記 5.2 ）。

\section{2 用途非課税の趣旨}

前記 1 のとおり, 法73条の 4 第 1 項は, 用途非 課税を規定する。同項の趣旨について，大阪地判 平成 24 年 7 月 5 日（LEX/DB 文献番号 25483036) (以下「平成 24 年大阪地判」という) は，「このよ うな場合には当該不動産が公益を目的とする用途 に供されると考えられることから，同項は，その ような場合に，政策的に不動産取得税を非課税と する趣旨であると解される。（下線筆者。以下同 じ）と説示する。また，福島地判平成 26 年 6 月 24 日（TAINS Z999-8340）（以下「平成26年福島地 判」という) は,「このような不動産の取得は,

\footnotetext{
(5) 前掲注 $(2)$ 及び $(3)$ 参照。

(6) 大阪府教育庁・大阪府総務部「学校法人森友学園瑞穂の國記念小學院設置認可申請に関する検証報告 - 府職員が校舎敷地を府審査 基準に適合すると判断したことの検証 -〔平成29年 4 月 6 日〕」 2 頁参照（同府HP(http://www.pref.osaka.lg.jp/hodo/attach/ hodo-27230_5.pdf[最終確認日：平成29年12月 1 日]))。

(7) 平成27年 1 月 30 日大私審第 15 号大阪府知事あて大阪府私立学校審議会答申「小学校の設置について」参照（同府HP(http://www. pref.osaka.lg.jp/attach/5807/00178564/270127toshin.pdf[最終確認日：平成29年12月 1 日]))。

(8) 大阪府教育庁 ·大阪府総務部 ·前掲注(6) 2 頁参照。

(9) 大阪府教育庁 ·大阪府総務部 · 前掲注(6) 2 頁参照。

(10) 第193回国会衆議院予算委員会議録・前掲注(1)10頁〔籠池康博証人発言〕。

(11) 大阪府「平成29年（2017年）3 月29日知事記者会見内容」〔松井一郎知事発言〕（同府HP(http://www.pref.osaka.lg.jp/koho/ kaiken/20170329.html[最終確認日：平成29年12月 1 日]))。
} 
それによって他の一般国民の公共の利益に資する ものであるから，これを非課税とし，そのような 不動産の取得に係る経済的負担を軽減することに よって当該法人等の活動を推進し，ひいては国民 の福利の増進を図る政策的な目的を有するものと 解することができる。と説示する。

上記各説示によると, 同項は, 公益性の観点か ら政策的に非課税とする規定であると解される。 また，同項が適用される者と適用されない者とを 比較すると, 不動産取得税に係る担税力 ${ }^{(2)}$ の点で は相違がないにもかかわらず，当該適用される者 の不動産取得税は非課税とされるから, 同項は, 租税負担の公平を犠牲にして, 当該適用される者 を優遇する規定であると解されよゔ。

\section{3 実際に非課税用途に供することは用途 非課税の適用要件か}

前記 1 のとおり，法73条の 4 第 1 項は，「使用 するために取得した場合」を非課税とする。これ を素直に読めば, 同項は, 非課税用途に供する目 的で取得したこと（以下「主観的要件」という） のみを要件としているように思われる。もっとも, 同項は，公益性の観点から政策的に設けられた規 定であるところ（前記 2 参照），実際に非課税用 途に供されない場合は公益に資することはないか ら，こうした場合に非課税とすることは，同項の 趣旨に反するように思われる。そうすると, 主観 的要件に加え, 実際に非課税用途に供すること （以下「客観的要件」という）も同項の要件に含 まれるようにも思われる。

そこで, 同項の適用要件を主観的要件のみと解
すべきか（同見解を以下「主観説」という），あ るいは，主観的要件に加え，客観的要件も必要と 解すべきか（同見解を以下「客観説」という）を， 以下検討する。

\section{1 主観説を採る見解}

以下の各見解は，主観説を採るものと解される。

\section{1. 1 高崎正幸氏の見解}

現行不動産取得税が創設される直前 ${ }^{(4)}$, 自治庁 府県税課職員であった高崎正幸氏は，「使用する ために取得」の判断基準について，「当該各号に 掲げる用途に使用するという機関の意志決定がな されているか，及び当該者が不動産を取得してか ら近い将来に機関意志通り当該各号に掲げる不動 産として使用するであろうということが客観的に 確実に推測されるかどうかによらざるをえない。」 という見解を公表した ${ }^{(15)}$ 。

\section{1. 2 石川一郎氏の見解}

現行不動産取得税が創設された翌年, 自治庁総 務部職員であった石川一郎氏は，「日本国有鉄道

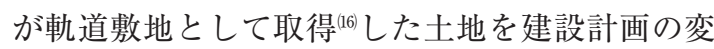
更に伴い不用に帰して放置されているような場合 においては，その本来の事業の用に供さないもの として課税して差し支えないでしょうか。とい う問いに対し，「その取得の時においてその本来 の事業の用に供するものであるか否かを認定して 課税の有無を決するものとされています。従つて 非課税とされるためには, その取得の時期におい て本来の事業の用に供するものであれば足り，そ の後にその用途の変更が行われたような場合にお いても，これに対して課税することはできませ ん。」という見解を公表した ${ }^{(17)}$ 。

\footnotetext{
(12) 不動产取得税に係る担税力について, 金子宏「判批」判評76号16１7頁（1965年）は,「不動産を取得する人は一般にほかにも経 済的負担能力をもっているであろうという推定の上に立って担税力をみとめているのであって, ここでの担税力の観念は所得税や 収益税の場合のように現実的裏付けをもったものではなく，もっと観念的なものなのである。と論じる。

(13) 租税優遇措置については，金子宏『租税法』(弘文堂，第22版，2017年）88～89頁参照。

(14) 現行不動産取得税は，地方税法の一部を改正する法律（昭和29年法律第95号）により創設された。同法律は昭和29年 5 月 13 日に公 布されたが, 高崎氏の見解は同年 4 月 1 日に公表された（税 9 巻 4 号148頁（1954年）参照）。

(15) 高崎正幸「不動産取得税」税 9 卷 4 号53頁 (1954年)。

(16) 同見解の公表当時, 法73条の 4 第 1 項は,「日本国有鉄道……直接その本来の事業の用に供する不動産で政令で定めるもの」(同 項 1 号)「として使用するために取得した場合においては, ……不動産取得税を課することができない。」(同項柱書) と規定していた。

(17) 石川一郎 $=$ 河西俊一『実例地方税総覧』(税務通信社，1955年）187頁〔石川〕
} 


\section{2 客観説と解され得る見解}

以下の各見解は, 主観説と見受けられる論述と 客観説と見受けられる論述を併せ持つ。各見解の 下線部をみると客観説と解されるが, 同下線部の 趣旨は必ずしも明らかではないから，ここでは, 客観説と解され得る見解と整理しておきたい。

\section{2. 1 石田直裕氏の見解}

石田直裕氏 (本見解公表時, 自治省府県税課職 員）は,「非課税用途に供されるものであるかは, 不動産を取得した時において認定するものであ る。」「認定を行うに当たつては, 当該法人の予算, 事業計画書, 議事録, 財産目録, 寄附書, 関係機 関の証明書を提出させてこれらを参考にすること が必要である。」「取得された不動産が現実に一定 の非課税用途に供される時期が取得の時より後に なる場合には, 取得後の使用状態が他の用途に供 されていない限り, 非課税として差し支えないも のと考えられるが, 非課税用途に供することなく 他の用途に転用されれば直ちに課税すべきは当然 である。従つて，このような場合には，実務上は 一応課税保留を行い, その目的たる用途に供され る状態になつて, その時に非課税として処理せざ るを得ないものと考えられる。と論じる(18)。

\section{2 . 2 石島弘教授の見解}

石島弘教授は，「一定の用途に供されるもので あるかどうかは, 不動産の取得時において, 当該 法人の予算, 事業計画書, 議事録, 財産目録, 寄 附書, 関係機関の証明書等によって認定すること になる。」「取得された不動産が現実に一定の非課 税用途に供される時期が取得の時より後になる場 合には, 取得後の使用状態が他の用途に供されて いない限り，非課税となるが，非課税用途に供す ることなく他の用途に転用されれば，その時点で 課税の対象になることは言うまでもない。」と論
じる ${ }^{(19)}$

\section{2. 3 碓井光明教授の見解}

碓井光明教授は, 「問題点は, 取得時において 現実に所定の用途に供されていることは少なく, 程度の問題とはいえ，『供する見込み』を認定し て課税をしない扱いにせざるを得ないので，後日 その用途が確定的になった時点において，どのよ うに対処するかという点である。賦課権を行使し うる期間内に供していないことが判明した場合に は，遡って課税することが可能である。」論じ る ${ }^{(20)}$ 。

\section{2.4 占部裕典教授の見解}

占部裕典教授は,「使用するために取得した場 合」の意義ではなく，「直接保育又は教育の用に 供する」の意義を限定的に解する。すなわち,「直 接保育又は教育の用に供する」の意義について, 「その規定の立法趣旨, ……課税物件の特質, 文理 解釈からして,」「不動産（土地）を取得したとき の客観的状況からして取得後すみやかに保育又は 教育の用に使用することが高度の蓋然性をもって 予測しうる場合」と解する ${ }^{(21)}$ 。その上で, 「学校法 人が学部の設置等にあたり取得した土地等の権利 の取得に，不動産取得税……が課せられるか否か について」は,「不動産を取得し, 学部等の設置 申請を行った段階では，当該不動産が非課税の対 象となる用途に用いられるのか，あるいは用いら れないのか, どちらつかずの状態のようにみえる が，(1)学校法人が『直接に保育又は教育の用に供 する』意図, 目的で当該不動産を取得しているこ とが学部等の設置に係る申請書の提出により推定 できること，(2)実務上，学部等の設置申請が受理 されれば設置認可の確率がかなり高いこと, (3)学 部の設置認可を受ければ, 当該不動産は『直接に 保育又は教育の用に供する』ために確実に使用さ

(18) 石田直裕「地方税法逐条解説（連載）不動産取得税（第六回）」地方税 31 巻 4 号 142 頁 (1980年)。なお，同旨の見解として，畠山 光美「地方税法逐条解説（連載）不動産取得税（第四回）」地方税19巻 4 号68頁（1968年）がある。

(19) 石島弘『不動産取得税と固定資産税の研究』(信山社, 2008年) 189 190頁 [初出:西村宏一ほか編『不動産関係税法 II - 地方税 -』 (青林書院, 1992年) 37頁〔石島弘〕。

(20) 碓井光明『要説 地方税のしくみと法』(学陽書房, 2001年) 224頁。

(21) 占部裕典『租税法における文理解釈と限界』(慈学社出版, 2013年) 841 頁。 
れること, などから, どちらつかずの, 白紙の状 態ではなく, 近い将来, 直接に保育又は教育の用 に供せられる確率が高い状態である。」「流通税た る不動産取得税……課税関係を取得のときに 『すべてか無か』として, ……学校法人に納税義務 を負わせないと解することも可能ではあるが, 学 部の設置認可がおりず，かつその資産が既存学部 のために直接に教育の用に供されない場合には, 課税庁がその時点でさかのぼって徵収を行うこと ができると解する方が, 非課税規定の趣旨からし て合理的であろう。」と論じる ${ }^{22}$ 。

\section{3 . 3 課税実務}

課税実務の取扱いについては, 次のとおり紹介 されている。

「取得された不動産が一定の非課税用途に供さ れる時期が取得の時より後になる場合には, 取得 後の使用状態が他の用途に供されていない限り, 非課税として差し支えないこととされており，実 務上は，一応課税保留を行い，その目的たる用途 に供される状態になって，その時に非課税として 処理せざるを得ないものと考えられてきた。しか し, 現在では, 一旦課税手続を行い, 非課税とし ての用途に供される状態になった時点で課税を取 り消し，納入済の税額があればそれを還付すると いう方法もとられている。」(23)

\section{4 裁判例}

主観的要件に加え, 客観的要件の要否を判示し た裁判例として, 平成24年大阪地判，平成26年福 島地判及び同福島地判の控訴審判決である仙台高 判平成 27 年 6 月 12 日判例集未登載（平成26年（行 コ）第15号）(以下「平成27年仙台高判」という) があるが，以下のとおり，いずれも主観説を採る。

\section{4.1 平成24年大阪地判}

平成 24 年大阪地判の事案の概要は, 次のとおり
である。すなわち, 社会福祉法人Xは, 児童福祉 施設を建築する目的で土地（以下「本件土地」と いう）を購入した。その後, 本件土地の一部につ いて土地区画整理法に基づく換地処分が行われた。 このため, Xは, 本件土地上ではなく, 換地上に 児童福祉施設を建築した。これに対し，府は，本 件土地上に児童福祉施設が建築されていないから， 法73条の 4 第 1 項 4 号の 2 (現行 4 号の 3 ) が規 定する非課税要件を満たさないとして，Xが本件 土地を取得したことに対して不動産取得税賦課決 定処分を行った。これを不服としたXは，当該処 分の取消しを求めて提訴した。

上記の事案において, 客観的要件の要否が争わ れた。この点, 府は,「本件非課税規定の趣旨に 照らすと, 本件非課税規定が適用されるには, ……実際に児童福祉施設等の整備の用に供するこ とが必要である」と主張した。これに対し，大阪 地裁は，「政策目的の実現を重視するのであれば, 不動産の取得時に課税関係を確定させるのではな $く, \cdots \cdots$ 現実に一定期間内に……当該政策目的に 適う方法で利用した場合に不動産取得税の免除を するという制度を採用することも十分に考えられ る」ことなど「に鑑みると，立法者は……非課税 用途に供するために不動産を取得したことが真実 であるのであれば，その後当該不動産が現実に非 課税用途に供されることがなかったとしても，な お非課税とすべきであると判断したとみる余地も ある。したがって, ……本件非課税規定の趣旨か ら直ちに, ……現実に非課税用途に……供したこ とが非課税要件として必要であることが導き出さ れるとはいえない。と判示した。

また，府は，「政策目的による非課税規定はみ だりに拡張解釈をすべきではなく，限定的に解釈 をすべきである」と主張した。これに対し，大阪

(22) 占部・前掲注(21) 842 頁。

(23) 田原英介「演習道府県税 不動産取得税の用途非課税」税43巻 9 号 202 頁 (1988年)。なお，桑折恭平「高校体育館を建設する目的 で土地を取得したが 5 年たっても建設されない場合不動産取得税を課せるか一不動産取得税の用途非課税措置」自治実務セミナー 643号34頁（2016年）は，「課税実務上は, ……用途非課税に当たる旨の申告があった場合にはいったん課税を保留し，その目的た る用途に供される状態になってから，非課税として処理する場合が多いところである。と紹介する。 
地裁は，「確かに，政策目的による非課税規定 ……については, 納税者間の公平を確保する観点 からみだりに拡張解釈をすべきではなく, 厳格な 解釈及び運用がされるべきことは被告指摘のとお りである。しかし,……条文の文言にない要件を 付加することは, 上記のような厳格な解釈及び運 用ということはできず, 納税者の予測可能性を著 しく害し, 法的安定性を損ねるものであって, 租 税法律主義に反するものとして原則として許され ないというほかない。」「以上に照らせば, ……非課 税用途……使用する目的を有していること（主 観的要件) は必要であるが,…現実に非課税用 途に供したこと（客観的要件）は，その要件とさ れていないものと解するのが相当である。と判 示した。

\section{4.2 平成26年福島地判}

平成26年福島地判の事案の概要は, 次のとおり である。すなわち, 病院を経営する財団法人Xが 病棟を取得したことに対し, 福島県は, 不動産取 得税賦課決定処分を行った。これに対し，Xは, 社会福祉法 2 条 3 項 9 号にいう無料低額診療事業 の用に供するために当該病棟を取得したのである から, 法73条の 4 第 1 項 4 号の 7 の規定により非 課税になると主張して, 当該処分の取消しを求め て提訴した。

上記の事案において, 福島地裁は, 次のとおり 判示した。

「法73条の 4 第 1 項柱書は『……使用するため に取得した場合……と規定しているところ，か かる文言を文理解釈すれば, 不動産の取得者が, その不動産の取得時において, 同項各号の不動産 として使用する目的を有していることを要件とし， かつそれで足りるとしているものと理解するのが 自然である。」「非課税規定を通覧しても，……司項 各号の用途に現に使用されていることを要件とす ることを示す文言は見当たらない。」「不動産の取
得という一時点の事実に担税力を認めその取得者 に対して課税する」という不動産取得税の「課税 根拠に照らせば, その非課税措置の適用要件の存 否も，不動産の取得という一時点を基準として判 断すべきものと解するのが自然かつ合理的であ る。」したがって, ……無料低額診療事業の用に供 する不動産として使用する目的を有していること はその要件であるが……, 実際に無料低額診療事 業の用に供されたことは要件ではないというべき である。」

\section{4.3 平成27年仙台高判}

平成27年仙台高判は, 「本件建物を社会福祉事 業としての無料低額診療事業の用に供する不動産 として使用するために取得したといえるか否かは， 本件建物を取得した時点において, 控訴人が本件 建物をどのように使用する目的であったかによっ て決せられることになる」と判示した。

\section{5 考察}

用途非課税の適用要件については, 主観説と客 観説のいずれを採るべきであろうか。

この点, 客観説によると, 実際に非課税用途に 供したか否かが基準となるから，主観説に比して 用途非課税の適否の認定が容易になるという利点 がある。また，実際に非課税用途に供しなければ 公益に資することはないから，主観説よりも客観 説の方が用途非課税の趣旨に適合するであろう ${ }^{24}$ 。 しかしながら, 法73条の 4 第 1 項柱書は, 「使 用するために取得した場合」と規定するから，そ の中に客観的要件が含まれると解することは, 文 理上，困難であると考えられる。また，法は，不 動産の取得後, 一定の期間内に生じた事情——例 えば, 取得した土地の上に一定の要件を満たす住 宅が新築されたこと（法73条の 24 第 1 項 1 号), 譲渡担保権者から譲渡担保財産の設定者に対して 当該財産が移転したこと（同73条の 27 の 4 第 1 項)——を要件として不動産取得税を軽減する規

(24) 平成26年福島地判は,「法の趣旨からすれば, 取得した不動産を現に無料低額診療事業の用に供している場合にのみ非課税とする ことが趣旨一貫するものともいえる。」と述べている。 
定を置いているが, 用途非課税には, こうした規 定がない。この観点からも客観的要件を必要とし ているとは認め難い。なぜなら, 客観的要件を必 要としているのであれば, 非課税用途に供される までの期間制限に関する規定が置かれていること が自然であるように思われるからである。さらに, 現行不動産取得税の創設の直前及び翌年に公表さ れた自治庁職員の見解（前記 3，1）がいずれも 主観説を採ることに鑑みれば，自治庁は，主観説 を想定して法案を作成したものと推測される。そ して, 制定された法 73 条の 4 第 1 項をみると, そ の文理上, 当該想定を表現したものと理解できよ う。

以上のことからすると, 用途非課税の適用要件 は，主観説を採るべきである。

\section{4 主観的要件の認定基準}

前記 3.5 のとおり, 用途非課税の適否は, 主 観的要件の有無によって判断すべきである。当該 有無に関する事実認定は, 課税団体である都道府 県——賦課決定処分取消訴訟においては裁判所 ——が行うものであるが, この事実認定の基準に 関しては, 次の 2 つの見解がある。1つは, 取得 時の事情をもって認定すべきであるという見解 (以下「取得時説」という) である。もう 1 つは, 取得時までの事情に加え, 取得後の事情も踏まえ て認定すべきであるという見解 (以下「総合考慮 説」という) である。いずれの見解を採るべきで あろうか。以下検討する。

\section{1 取得時説}

長島弘准教授は,「本件非課税規定の適用要件 の判断にかかる考慮すべき事情は, 不動産取得時 点の事情に限られ, 取得後の事情は考慮されるべ き事情にはならないというべきである。なぜなら， 取得時点の担税力は, 当該時点で判断されるべき ところ, 取得後の事情という, 偶然が左右する内 容によって, 遡って賦課時点〔「取得時点」の誤
りと思われる。以下同じ」の担税力が左右される ということは不合理であるからである。と論 じ25), 取得時説を採る。

\section{2 総合考慮説}

以下の各裁判例は, いずれも総合考慮説を採る。

\section{2 . 1 平成24年大阪地判}

平成 24 年大阪地判は, 次のとおり判示する。

「不動産の取得目的は取得者の主観面に関わる 事情であり，その認定には困難を伴うことも考え られる上に，政策目的の非課税規定の適用に当 たっては厳格な審査が必要であることをも踏まえ ると, ……取得後の事情を考慮することがおよそ 許されないものということはできない。「非課税 用途に供するため不動産を取得したか否かについ ては，当該不動産の取得に係る契約書，事業計画 書, 当該不動産の取得者の財産状況等不動産取得 までに生じた事情のほか，当該不動産が非課税用 途に現実に供されたか否か，仮に当該不動産が非 課税用途に供されなかった場合にはその経緯や理 由などの諸般の事情を踏まえて，認定されるべき ものと解される。」このように解すると，……不動 産の取得後, 当該不動産が非課税用途に現実に供 されなかった場合には, 当該不動産の取得時にお いても, 当該不動産を非課税用途に使用する目的 を有していなかったことが事実上推認されるのが 通常と解される」。「なお, ……認定すべきはあく までも当該不動産取得における非課税用途に使用 する目的の有無であって，これを取得後の事情も 加味しつつ判断するというにすぎないから，…... 後発的な事情によりやむを得ず当該土地を非課税 用途に供しなかったような事案についても，本件 非課税規定はおよそ適用されないという」べきで はない。

\section{2 . 2 平成27年仙台高判}

平成 27 年仙台高判は, 次のとおり判示する。

「どのように使用する目的であったかは，控訴 人における寄附行為の定めや社会福祉法に基づく 
社会福祉事業開始の届出の有無といった形式面及 び本件建物における控訴人の実際の活動等の実体 面の双方から総合的に検討して客観的に判断すべ きものである。そして，本件建物における控訴人 の実際の活動等は, 本件建物取得前後の客観的事 実により認定すべきである（本件建物取得前後の 客観的事実を検討することによって本件取得時に おける本件建物の使用目的が何であったかを客観 的に判断するものであって, このことは, 使用目 的の判断基準時が本件建物取得時であることと矛 盾するものではない。)。」「また, 無料低額診療事 業という公益的性格の強い事業に利用されるため 取得された不動産について不動産取得税が非課税 とされるのであるから, 一般の診療事業と併用し て使用される不動産が非課税とされるためには, ……当該不動産において無料又は低額の診療が継 続的に行われる体制や設備が整えられ，かつ，実 際に相当数の無料又は低額の診療が反復継続して 行われている場合に，公益的性格の強い事業が現 実に行われているとして, 無料低額診療事業に供 するために取得されたということができると解さ れる。」

\section{3 考察}

主観的要件の認定基準については, 取得時説と 総合考慮説のいずれを採るべきであろうか。

この点, 取得時説を採る長島准教授は, 「取得 後の事情という, 偶然が左右する内容によって, 遡って賦課時点の担税力が左右されるということ は不合理である」と論じる ${ }^{20}$ 。確かに, 実際に非 課税用途に供したことを用途非課税の適用要件と 解すると，「偶然が左右する内容によって」「担税 力が左右される」といえる。

しかしながら，「非課税用途に現実に供された か否か, 仮に当該不動産が非課税用途に供されな かった場合にはその経緯や理由などの諸般の事情
を踏まえて」(27)，飽くまで主観的要件の有無を認 定するのであれば,「偶然が左右する内容によっ て」「担税力が左右される」とはいえないであろう。 また，「取得目的は取得者の主観面に関わる事情 であり，その認定には困難を伴うことも考えられ る」から (28), 取得後の事情を考慮する必要性は認 められる。さらに, 主観的要件の認定について制 限する法令は存在しないから ${ }^{29}$, 取得後の事情を 考慮することも許容されるであろう。

以上のことからすると, 主観的要件の認定基準 は，総合考慮説を採るべきである。

\section{5 「使用するために取得」の意義}

前記 3.4 の各裁判例はいずれも主観説を採る が,「使用するために取得」の解釈に関し, 不動 産の取得時における非課税用途に供される蓋然性 の程度は明示していない。そうであるにもかかわ らず，平成 24 年大阪地判は，(1「非課税用途に現 実に供されなかった場合には, 当該不動産の取得 時においても, 当該不動産を非課税用途に使用す る目的を有していなかったことが事実上推認され るのが通常と解される」と判示する。確かに,「使 用するために取得」の範囲を，不動産の取得時に おいて非課税用途に供される蓋然性が高い場合に 限定すると，(1)解釈は成り立ち得るであろう。 しかしながら, 当該蓋然性が低い場合も含まれる とすると, (1)解釈は成り立ち得ないであろう。 なぜなら, 当該蓋然性が低い場合は, 不動産の取 得後に非課税用途に供されないこともまれなこと ではないと考えられるからである。そうであると すると, 同地判は, 当該範囲を明示すべきであっ たと考えられる。

また, 平成27年仙台高判は, 2 「実際に相当数 の無料又は低額の診療が反復継続して行われてい る場合に……無料低額診療事業に供するために取

(26) 長島·前掲注(25)348頁。

(27) 平成 24 年大阪地判。

(28) 平成 24 年大阪地判。

(29) 平成26年福島地判参照。 
得されたということができると解される。」と判 示する(30)。2は，実際に非課税用途に供されてい ることをもって「使用するために取得」されたと 解するものである。しかしながら，同高判が採る 主観説（前記 3.4. 3 参照）と2とは矛盾する であろう（客観説と(2とは整合性を有する） ${ }^{(31)}$ 。

以上のとおり, 前記各裁判例には解釈上の問題 があるといえる。そこで,「使用するために取得」 の意義をいかに解すべきかを，以下検討する。

\section{1 考察}

「使用するために取得」は, 用途非課税の適用 要件である。こうした非課税要件規定は, どのよ うに解釈すべきであろうか。この点，仙台高判昭 和50年 1 月 22 日行集 26 巻 1 号 3 頁は, 「租税法規 ことに課税要件規定は狭義に厳格になされなけれ ばならないことは異論のないところであろうが, 租税法規における非課税要件規定は, 課税要件規 定を原則的規定とすると，これに対する例外的規 定としての地位にあるものと理解され, 実質的に も非課税要件規定は, それが課税要件規定とは異 なる何らかの財政，経済政策的配慮から定立され るものであるが故に, 課税要件規定が実現維持し ようとする租税負担の公平等の理念に対して何ら かの意味におけるいわゆる阻害的な影響を及ぼす ものであることからして, 租税法規の解釈適用に おける前記の狭義性, 厳格性の要請は, 非課税要 件規定の解釈適用において一層強調されてしかる べきだからである。と判示する(32。こうした解 釈は, 用途非課税の適用要件にも妥当するであろ う。

それでは，どのような観点から「使用するため
に取得」を狭義・厳格に解釈すべきであろうか。 この点, 次の 2 つの見解が参考となろう。

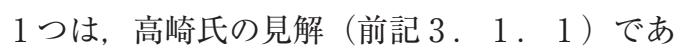
る。高崎氏は,「使用するために取得」の判断基 準について，「当該各号に掲げる用途に使用する という機関の意志決定がなされているか, 及び当 該者が不動産を取得してから近い将来に機関意志 通り当該各号に揭げる不動産として使用するであ ろうということが客観的に確実に推測されるかど うかによらざるをえない。」と説く ${ }^{(3)}$ 。同見解は, 現行不動産取得税が創設される直前に「二十九年 度地方税制改正解説特集」(34)して自治庁職員が 解説したものであり，法案を作成した自治庁の見 解と推測されるから,「使用するために取得」を 解釈する際の参考となろう。

もう 1 つは, 占部教授の見解（前記 3.2 . 4 ）である。占部教授は，「直接保育又は教育の 用に供する」の意義を「不動産（土地）を取得し たときの客観的状況からして取得後すみやかに保 育又は教育の用に使用することが高度の蓋然性を もって予測しうる場合」と解する ${ }^{350}$ 。同見解は, 「使用するために取得」を解釈したものではない が, 解釈の方向性としては, 高崎氏の見解と共通 するといえよう。

上記各見解は，いずれも非課税用途に供される までの期間及び非課税用途に供される蓋然性の程 度を要素としているが, 妥当であろう。なぜなら, 取得時から非課税用途に供されるまでの期間が長 期に及ぶと推測される場合, 又は非課税用途に供 される蓋然性が低いと推測される場合は, 取得後, 非課税用途以外の用途に供される可能性が低いと

(30) 平成26年福島地判も「不動産を取得した時までに……実際に相当数の無料低額診療患者の診療を反復継続して行っていたという事 情が認められるか (継続事業の場合)，あるいは, ……不動産を取得した後相当期間が経過するまでに……実際に相当数の無料低額 診療患者の診療を反復継続して行ったという事情が認められること（新規事業の場合）が必要であると解するのが相当である。」 と判示する。

(31) なお, 長島・前揭注(25)346頁は, 平成26年福島地判の前掲注(30)などの判示と前記 3．4．２の判示を「明らかな自己矛盾」と論じる。

(32) 同高判の上告審判決である最判昭和53年 7 月 18 日訟月 24 巻 12 号 2696 頁は, 「非課税規定は厳格に解釈すべきであるとした原審の判 断は，正当として是認することができる」と判示する。

(33) 高崎・前揭注(15)53頁。

(34) 税 9 巻 4 号 2 頁 (1954年)。

(35) 占部・前掲注(21)841頁。 
はいえず，こうした場合にまで非課税とすること は, 納税者間の公平の観点から不合理といえるか らである。

そして, 上記各見解のように, 不動産の取得後, 「近い将来」又は「すみやかに」, 非課税用途に供 されることが「客観的に確実に推測される」又は 「高度の蓋然性をもって予測しうる」場合は, 不 動産の取得後に非課税用途に供されることは通常 のことといえよう。もっとも，こうした場合で あっても, 非課税用途に供されないことも生じ得 る。例えば, 取得した不動産が収用や土地区画整 理事業等により使用することが不可能となった場 合や，取得した不動産が災害等により滅失した場 合など，取得者の責めに帰することのできないや むを得ない事情が生じた場合が考えられよう。

以上のことを踏まえると，「使用するために取 得」とは, 取得者の責めに帰することのできない やむを得ない事情のない限り, 取得後相当期間内 に非課税用途に供する意思をもって行われた取得 と解すべきであろう。

\section{2 学園に対する用途非課税の適否}

「使用するために取得」の意義を前記 5.19 とおり解した場合, 学園による前記 1 の土地の取 得に対し, 用途非課税は適用されるであろうか。

この点, 学園は, 小学校の設置認可申請後, 同 小学校の設置予定日の10箇月前に土地を取得して いるから, 特段の問題がなければ,「使用するた めに取得」に該当しそうである。しかしながら, 学園は, その後, 同申請を取り下げ, 同小学校は 設置されなかった。その理由が, 府知事の認識ど おり同申請書類の虚偽に求められ, 当該虚偽がな ければ同小学校が設置できていたと考えられ（前
記 1 参照), かつ, 同申請書類の補正が不可能な ものであったとすれば, 学園による同土地の取得 は，取得者の責めに帰することのできないやむを 得ない事情のない限り, 取得後相当期間内に非課 税用途に供する意思をもって行われた取得とは認 められないから（取得時に存在した同申請書類の 虚偽という事情は，たとえ取得後に判明したとし ても, 主観的要件の認定の要素となろう), 用途 非課税は適用されないであろう。

\section{6 おわりに}

本稿では, 不動産取得税に係る用途非課税の適 用要件を検討した。この点, 課税実務は, 非課税 用途に供される状態になったことを受けて非課税 とするか, 又は課税を取り消している（前記 3 . 3 参照)。しかしながら, 用途非課税は, 非課税 用途に供する目的で取得したという主観的要件の みを要件とするから（前記 3 . 5 参照), 課税実 務が，実際に非課税用途に供したという客観的要 件を用途非課税の適用要件と解しているのであれ ば，その取扱いは是正されるべきであろう。

また, 用途非課税は, 公益性の観点から政策的 に設けられた規定であるから（前記 2 参照), 納 税者間の公平を図る観点から, 狭義・厳格に解釈 すべきである（前記 5 . 1 参照）。このように解 釈し，かつ，主観的要件を取得時までの事情に加 え, 取得後の事情も踏まえて認定すべきであると いう総合考慮説（前記 4.3 参照）を採ることに よって, 用途非課税の適用範囲が相当程度明確と なり，かつ，主観的要件に関する事実認定の困難 性も緩和されることとなろう。 